is it ever to be expected that the particular restricted area will comprise a very large proportion of a city's total area. Nonetheless, the suggested approach is still relevant since the cases most often arise in cities having a substantial Negro population and in which all the restricted areas together constitute a specified large proportion of the total.47 It seems that when a court considers only the particular covenant in issue it is disregarding the fact that enforcement of one covenant means enforcement of all like covenants, and as an agency of the state ${ }^{8}$ it is actually enforcing a discriminatory situation by judicial decision which Buchanan v. Warley bars the states from creating by legislation. Moreover, the value of this approach need not necessarily depend upon a specified percentage of a city's area being restricted, for the same racial zoning result is achieved where only that part of a city's area which immediately surrounds the "black belt" or protects the more desirable residential districts of the city is restricted.

The cases indicate that, on the whole, the new attacks on restrictive covenants so far have been met by a firm adherence to precedents originating in the older types of attack. Although there is no showing of social data in the record in either of the cases in which the Supreme Court has granted certiorari, if the Court should consider the data and arguments in the amicus briefs in Sipes $v$. McGhee or grant certiorari, in Hurd v. Hodge, it will have before it a complete presentation of the attacks on restrictive covenants. The weight of precedent in the state courts and the improbability of direct legislation outlawing covenants make it evident that the Supreme Court in granting certiorari affords, perhaps, the major hope of ameliorating one of the most critical areas of racial tension in contemporary American life.49

\title{
RECENT APPLICATIONS OF THE CIVIL-CRIMINAL CONTEMPT DISTINCTION
}

The distinction between civil and criminal contempt, always troublesome, played an important part in United States v. United Mine Workers, where the Supreme Court approved the procedure used by the District Court in imposing a fine combining both civil and criminal elements in a single contempt proceeding. Mr. Justice Rutledge, in his dissent in the Mine Workers case ${ }^{2}$ and again in

47 For example: "The exact extent of the restrictive covenant has not been ascertained, but 'in Chicago it has been estimated that $80 \%$ of the city is covered by such agreements. ...." " Myrdal, op. cit. supra note 35 , at 624 .

$.4^{8}$ Authorities cited note 3 I supra.

49 What the Supreme Court will decide is conjectural, but if it should decide only that injunctions in such cases are unconstitutional, without determining that restrictive covenants are themselves void, the question of damages might become prominent. It is the remedy of enforcement by injunction, however, that effectively and necessarily prevents Negroes from acquiring restricted property.

× 67 S. Ct. 677 (1947).

267 S. Ct. 677, ' 20 (1947). 
Penfield Co. 0. Securities \& Exchange Commission, ${ }^{3}$ has vigorously attacked such procedure. He contends that it violates the Constitution, clear judicial precedents, and the rules of criminal procedure. ${ }^{4}$ Under the Taft-Hartley Act, ${ }^{5}$ injunctions may become an important incident of the government's regulatory activities in the field of Jabor relations; it is therefore regrettable that there should be confusion and doubt as to the procedural aspects of injunction enforcement.

The difficulties that have plagued both courts and writers ${ }^{6}$ in their analysis of the contempt power are perhaps caused by the breadth of the term "contempt," which includes, among others, such widely divergent elements as the power of a court of equity to compel obedience to its in personam decrees and the power of any court to punish those who misconduct themselves in the courtroom. The contempt power is sometimes analyzed on the basis of the character of the contemptuous act; ${ }^{7}$ it is said, in general, that a contempt is criminal when it involves a wilful and obstructive defiance of a court's authority, but that a contempt is civil if its primary effect is to injure the opposing party in the litigation. ${ }^{8}$ This analysis breaks down, however, when applied to the violation of an injunction, where the contemptuous act is both a defiance of the court and an injury to the opposing party. ${ }^{9}$ In the injunction situation, the criminal-civil distinction comes into play only after action is taken against the party in contempt. The proper analysis rests on the nature of the sanctions invoked rather than on the character of the contemptuous act. ${ }^{10}$ When punitive measures are sought, in the form of fixed fines or terms of imprisonment, the contempt is con-

367 S. Ct. 918, 923 (1947).

4 In support of the Rutledge position see Watt, The Divine Right of Government by Judiciary, I4 Univ. Chi. L. Rev. 409, 449-5I (1947).

$s$ Labor Management Relations Act, r947, 29 U.S.C.A. \& 160 . The act permits, and in certain situations directs, the Labor Board to apply to the courts for injunctive relief.

${ }^{6}$ See Beale, Contempt of Court, Criminal and Civil, 2r Harv. L. Rev. I6r (Igo8). The distinction between civil and criminal contempt and its application by the courts in injunction cases is exhaustively discussed in Moskovitz, Contempt of Injunctions, Civil and Criminal, 43 Col. L. Rev. 780 (1943). Further inquiry is needed only in the light of the problem of mixed proceedings raised by the Mine Workers case.

7 Thomas, Problems of Contempt of Court 2 (x934); Rapalje, Contempt § 2I (I884).

${ }^{8}$ The distinction is sometimes made between refusing to do an act commanded (civil), and doing an act that has been forbidden (criminal). Gompers v. Bucks Stove \& Range Co., $22 I$ U.S. 4 I8, 443 (rgIr). Contempts may be considered criminal when they are especially wilful or "contumacious," or when the act involved is also an indictable crime. Moskovitz, op. cit. supra note 6, at 793 ff.; see In re Eskay, I22 F. 2d 8I9 (C.C.A. 3d, r94r); In re Fox, 96 F. 2d 23 (C.C.A. $3^{\mathrm{d}}$, $\mathrm{I938}$ ).

9 Lamb v. Cramer, 285 U.S. 2I7, 22 (I932); Bessette v. W. B. Conkey Co., I94 U.S. 324 , 329 (I9O4).

so "It is the purpose of the punishment, rather than the character of the act punished, which determines whether the proceeding is for civil or criminal contempt." Lamb v. Cramer, 285 U.S. 21 7, 220 (1932); see Gompers v. Bucks Stove \& Range Co., 22I U.S. 4I8, 443 (I9II); In re Nevitt, II7 Fed. 448,458 (C.C.A. 8 th, 1902). 
sidered criminal; if, however, the sanctions are to be coercive and remedial, in the form of fines or imprisonment contingent on continued disobedience, or of fines payable as compensation to the complainant, the contempt is civil. ${ }^{\text {.r }}$ The distinction is important since it will control the procedure by which the party in contempt is tried. If civil remedies are involved the contemnor is considered to have the power to avoid the penalties by compliance with the court's decree, ${ }^{12}$ and he is therefore given no protections beyond those afforded to any party in a suit in equity ${ }^{x_{3}}$ the defendant in a case of criminal contempt, on the other hand, is surrounded by almost all of the safeguards of an accused in a regular criminal action, except for the right to a trial by jury..$^{\mathrm{IA}} \mathrm{It}$ is the contention of Mr. Justice Rutledge that these important procedural differences are threatened with extinction if a court may impose both civil and criminal sanctions in a single contempt proceeding.

Mr. Justice Rutledge, in his dissent in the Mine Workers case, first attacked the use of a single mixed proceeding on broad constitutional grounds, pointing out that under our system civil and criminal procedures are sharply differentiated and never mixed, and that, in fact, the differences "mark one of the great constitutional divides." "Is The problem is whether that general principle need be applied to contempt proceedings, which are admittedly unique. The contempt. procedure must be judged, not in the light of broad generalities, but in terms of specific rights protected or abused. ${ }^{16}$

II The distinction is perfectly workable even though civil (remedial) relief may have incidental criminal (punitive) effects, and vice versa. Moskovitz, op. cit. supra note 6, at 786 .

72 The Anglo-American system is unique in its assumption that the coercive power of the courts is absolute and that no one is privileged to disobey the lawful order of a court. Pekelis, Legal Techniques and Political Ideologies: A Comparative Study, 4I Mich. L. Rev. 665, 66776 (I943). Moreover, the contemnor's intent is not material. Telling v. Bellows-Claude Neon Co., 77 F. $2 d 584$ (C.C.A. 6th, I935); Proudfit Loose Leaf Co. v. Kalamazoo Loose Leaf Binder Co., 230 Fed. 120, 132 (C.C.A. 6th, I915); Indianapolis Water Co. v. American Strawboard Co., 75 Fed. 972 (C.C. Ind., 1896 ).

${ }^{23}$ There is no presumption of the defendant's innocence; the proof of the violation need only be "clear and convincing." Telling v. Bellows-Claude Neon Co., 77 F. 2d 584 (C.C.A. 6th, 1935); Coca-Cola Co. v. Feulner, 7 F. Supp. 364 (Tex., I934).

${ }^{14}$ The defendant is given the presumption of innocence. Gompers v. Bucks Stove \& Range Co., 22I U.S. 4I8, 444 (IgII); United States v. Balaban, 26 F. Supp. 49 I (Ill., I939). Proof of the violation must be beyond a reasonable doubt. Gompers v. Bucks Stove \& Range Co., 221 U..S. 418, 444 (I9II); Sabin v. Fogarty, 70 Fed. 482 (C.C. Wash., 1895 ). The defendant enjoys the privilege against self-incrimination. Gompers v. Bucks Stove \& Range Co., 221 U.S. 4I8, 444 (I III); Hammond Lumber Co. v. Sailors' Union of the Pacific, I67 Fed. 809 (C. C. Cal., I909); United States v. Balaban, 26 F. Supp. 49I (Ill., I939). There can be no review of an order dismissing criminal contempt charges. United States ex rel. West Virginia-Pittsburgh Coal Co. v. Bittner, II F. $2 d 93$ (C.C.A. 4th, I926). One convicted of criminal contempt may be pardoned. Ex parte Grossman, 267 U.S. 87 (r925). But in the absence of statutory authority a criminal contempt defendant is not entitled to trial by jury. Michaelson v. United States, 266 U.S. 42 (I924); Donato v. United States, 48 F. $2 \mathrm{~d} \mathrm{I42} \mathrm{(C.C.A.} 3 \mathrm{~d}$, I93I); Armstrong v. United States, I8 F. 2d 37 I (C.C.A. 7 th, I927).

${ }_{25}$ United States v. United Mine Workers, 67 S. Ct. 677,730 (I947).

${ }^{16}$ The courts often point out that contempt proceedings are "sui generis" and that formulas based on practices in other fields of the law may not be applicable Blackmer v. United States, 
Mr. Justice Rutledge's second contention was that the mixed proceeding in the Mine Workers case violated the strong precedent of Gompers v. Bucks Stove \& Range Co. ${ }^{17}$ It should be noticed that the Gompers decision did not involve a single proceeding resulting in both civil and criminal penalties. Gompers, as president of the American Federation of Labor and editor of the American Federationist, was enjoined from continuing a boycott against the complainant's products; when the injunction was disobeyed, Gompers was cited for contempt and sentenced to a year in prison. The Supreme Court reversed the judgment on the ground that punitive measures may be imposed only in a proceeding "instituted and tried as for criminal contempt," ${ }_{18}$ and that the proceeding against Gompers had been primarily civil and not criminal. In the proceedings against Gompers the contempt matter had been treated as part of the main equity cause, the equity plaintiff had been the prosecuting party with the government taking no part, and the defendant had been called as a witness against himself; these and several other characteristics of the proceeding were consistent with an action for civil but not for criminal contempt. The Court pointed out that a defendant in a criminal contempt action was guaranteed certain important protections, but that such safeguards would be of no help to him if he were not given warning that the measures to be taken would be punitive rather than remedial. The gist of the decision, therefore, clearly seems to be that a contempt defendant must have notice of criminal charges against him before punitive measures may be imposed. ${ }^{x 9}$

The federal courts have unanimously followed the Gompers case ${ }^{20}$ but, until Mr. Justice Rutledge's dissent in the Mine Workers case, there was no suggestion that the Gompers decision had forbidden the imposition in a single proceeding of both civil and criminal penalties. The courts in each case have scrutinized contempt proceedings which resulted in criminal penalties to see that there was no "variance between the procedure adopted and the punishment imposed." $2 x$ Following the method of the Gompers case, the courts look for a number of particularly indicative earmarks. If the contempt proceeding is entitled and treated as a part of the main equity cause there may be a presumption that only remedi-

284 U.S. 42 I, 440 (I932); Conley v. United States, 59 F. 2d 929, 935 (C.C.A. 8th, I932); Armstrong v. United States, 18 F. 2d 37r, 372 (C.C.A. 7th, r927); United States v. Balaban, 26 F. Supp. 49r, 498 (Ill., I939). For a particularly unfortunate use of the phrase "sui generis" in dealing with a question of specific rights, see the dissenting opinion of Mr. Justice Frankfurter in Penfeld Co. v. Securities \& Exchange Commission, 67 S. Ct. 9r8, at 930.

${ }^{77} 22$ I U.S. 4 r8 (I9II).

18 Ibid., at 444 .

I9 McCann v. New York Stock Exchange, 80 F. 2d 2rx (C.C.A. 2d, I935); In re Guzzardi, 74 F. 2d 67I (C.C.A. 2d, I935); Shulman v. Uniteḍ States, r8 F. 2d 579 (C.C.A. 6th, I927); Monroe Body Co. v. Herzog, 18 F. 2 d 578 (C.C.A. 6th, I927).

${ }^{20}$ Citation of cases is unnecessary; almost every federal case involving the distinction between civil and criminal contempt uses the Gompers decision as its precedent.

2x Gompers v. Bucks Stove \& Range Co.,.22I U.S. 4I8, 449 (IgII). 
al relief is contemplated.2 The wording of the prayer for relief is. often taken to indicate the nature of the action, ${ }^{23}$ although such words as "punishment" may be considered equivocal and not conclusive. ${ }^{24}$ The parties, by their actions, may reveal their understanding of the proceeding; ${ }^{25}$ if the complainant, for instance, requests the payment of costs to himself ${ }^{26}$ or calls the contemnor as a witness, ${ }^{27}$ he clearly cannot claim to have criminal penalties in mind. The Second Circuit Court of Appeals, in an effort to dispel the uncertainty arising from the use of this general "earmark" test, has adopted the rule that the identity of the prosecuting party may be conclusive in that criminal penalties cannot be imposed unless the contempt is prosecuted by a government attorney or by a private attorney specially appointed by the court to vindicate its authority..$^{28}$

The Federal Rules of Criminal Procedure, ${ }^{29}$ in effect since March of 1946 , embody the Second Circuit Court's suggestion in Rule 42 (b), which states, in part: "A criminal contempt [excepting those that occur in open court] shall be prosecuted on notice. The notice shall state the time and place of hearing, allowing a reasonable time for the preparation of the defense, and shall state the essential facts constituting the criminal contempt charged and describe it as such. The notice shall be given orally by the judge in open court in the presence of the defendant or, on application of the United States attorney or of an attorney appointed by the court for that purpose, by an order to show cause or an order of arrest." Rule ${ }_{42}$ (b) was violated in the Mine Workers case, in that the

${ }_{22}$ Norstrom v. Wahl, 4I F. 2d 910 (C.C.A. th, r930); Wakefield v. Housel, 288 Fed. 7r2 (C.C.A. 8th, I923); S. Anargyros v. Anargyros \& Co., Igr Fed. 208 (C.C. Cal., IgII); The Navemar, 17 F. Supp. 495 (N.Y., 1936). But see Nye v. United States, 313 U.S. 33, 42 (x94I); In re Kaplan Bros., 213 Fed. 753 (C.C.A. 3 d, I9I4), cert. den. sub nom. Kaplan v. Leech, 234 U.S. 765 (IgI4); Phillips Sheet \& Tin Plate Co.v. Amalgamated Ass'n of Iron, Steel \& Tin Workers, 208 Fed. 335 (D.C. Ohio, I913); United States v. Huff, 206 Fed. 700 (D.C. Ga., I9I3).

${ }^{23}$ Western Fruit Growers v. Gotfried, r36 F. 2 d 98 (C.C.A. gth, 1943); Monroe Body Co. v. Herzog, I8 F. 2d 578 (C.C.A. 6th, I927); Shulman v. United States, I8 F. 2d 579 (C.C.A. 6th, I927); In re Kaplan Bros., 213 Fed. 753 (C.C.A. 3d, I914), cert. den. sub nom. Kaplan v. Leech, 234 U.S. 765 (rgr4); In re Kahn, 204 Fed. 58r (C.C.A. 2d, Igr3); Kreplik v. Couch Patents Co., Igo Fed. 565 (C.C.A. Ist, rgII); S. Anargyros v. Anargyros \& Co., IgI Fed. 208 (C.C. Cal., I9II).

24 In re Guzzardi, 74 F. $2 d$ 6 67x, 672 (C.C.A. 2d, 1935 ).

${ }_{25}$ Kreplik v. Couch Patents Co., Igo Fed. 565, 570 (C.C.A. Ist, IgrI). But see National Popsicle Corp. v. Kroll, I04 F. 2d 259 (C.C.A. 2d, I939), where the court refused to consider "equivocal remarks made by court or by counsel."

${ }^{26}$ Gompers v. Bucks Stove \& Range Co., 221 U.S. 4I8, 447 (IgII).

27 Wakefield v. Housel, 288 Fed. 7 12 (C.C.A. 8th, I923).

${ }^{28}$ National Popsicle Corp. v. Kroll, 104 F. 2d 259 (C.C.A. 2d, 1939); McCann v. New York Stock Exchange, 80 F. 2d 21 I (C.C.A. 2d, I935), noted in 46 Yale L. J. 326 (I936); In re Guzzardi, 74 F. 2d 67 I (C.C.A. 2d, I935). Other courts have used the test but have not considered it conclusive. Nye v. United States, 3r3 U.S. 33, 42 (r94r); Western Fruit Growers v. Gotfried, 136 F. 2 d 98 (C.C.A. gth, I943); Norstrom v. Wahl, 4I F. 2d 910 (C.C.A. 7 th, 1930); The Navemar, I7 F. Supp. 495 (N.Y., I936); Phillips Sheet \& Tin Plate Co. v. Amalgamated Ass'n of Iron, Steel \& Tin Workers, 208 Fed. 335 (D.C. Ohio, Igr3).

29 I8 U.S.C.A. following $\$ 687$ (Supp., I946). 
petition for a rule to show cause, while stating the "essential facts constituting the criminal contempt," did not specifically describe it "as such." $3^{\circ}$ The Supreme Court decided, however, that the defendants had been given actual notice of the criminal charges against them so that the violation of Rule 42 (b) was not reversible error..$^{3 \pm}$ Whether or not one agrees with the Court's ruling, it was clearly within the Court's discretion under the "harmless error" provision embodied in Rule $5^{2}(\mathrm{a})^{32}$ to decide that the basic rule had been followed and that the formal discrepancy had caused no substantial harm. ${ }^{33}$

Assuming that there was adequate compliance with the requirements of notice in the Mine Workers case, the problem remains as to the propriety of a single proceeding in which civil and criminal contempt elements are mixed. The lower federal courts, both before ${ }^{34}$ and since ${ }^{35}$ the Gompers decision, have used such mixed procedure in a number of cases. The Supreme Court has never passed on the question specifically, but a few cases involving the mixture have been before the Court and have not met with disapproval. ${ }^{36}$ The same Court that handed down the Gompers decision, in fact, a year later followed the rule that when civil and criminal contempts are adjudicated in a single proceeding the criminal element dominates and determines the procedure for review, ${ }^{37}$ a

${ }^{30}$ United States v. United Mine Workers, Transcript of Record, at p. 66.

3 United States v. United Mine Workers, 67 S. Ct. 677, 697-700 (I947). The government's petition for rule to show cause was strongly worded in terms of "punishment," and the defendants in their motion to discharge the rule and the arguments thereon indicated their realization of the criminal charges. Transcript of Record, pp. 66, 82, r9o-95. The government's theory of action was thoroughly discussed between the parties and the court before the actual trial for the contempt was begun. Ibid., I95-20I.

32 "Any error, defect, irregularity or variance which does not affect substantial rights shall be disregarded." Federal Rules of Criminal Procedure, 18 U.S.C.A. following $\$ 687$ (Supp., I946). See also Section 269 of the Judicial Code, 4 O Stat. II 8 I (I9 I9), 28 U.S.C.A. § 39 I (I928).

33 The proper scope of the "harmless error" rule has been a troublesome question. See Kotteakos v. United States, 328 U.S. 750 (I946); United States v. Ragen, 314 U.S. 5 I2 (1942); Berger v. United States, 295 U.S. 78 (r935); United States v. Antonelli Fireworks Co., I55 F. 2d 63 I (C.C.A. 2d, 1946).

34 Continental Gin Co. v. Murray Co., I62 Fed. 873 (C.C.A. 3 d, I908); Christensen Engineering Co. v. Westinghouse Air Brake Co., I35 Fed. 774 (C.C.A. 2d, I905); Chicago Directory Co. v. United States Directory Co., I23 Fed. r94 (C.C.N.Y., r903); Cary Mfg. Co. v. Acme Flexible Clasp Co., I08 Fed. 873 (C.C.A. 2d, Igor); Sabin v. Fogarty, 7o Fed. 482 (C. C. Wash., I895); Hendryx v. Fitzpatrick, I9 Fed. 810 (C.C. Mass., 1884).

35 Union Tool Co. v. Wilson, 259 U.S. Io/ (I922); Wilson v. Byron Jackson Co., 93 F. $2 d$ 577 (C.C.A. 9 th, I937), noted in I6 N.C.L. Rev. 389 (1938); Merchants' Stock \& Grain Co. v. Board of Trade, 201 Fed. 20 (C.C.A. 8th, I9I2); Kreplik v. Couch Patents Co., xgo Fed. 565 (C.C.A. Ist, xgII); see Woodside v. United States, 60 F. 2d 823 (C.C.A. 4th, I932); Proudfit Loose Leaf Co. v. Kalamazoo Loose Leaf Binder Co., 230 Fed. I20 (C.C.A. 6th, I9r5); Morehouse v. Giant Powder Co., 206 Fed. 24 (C.C.A. gth, I913); Phillips Sheet \& Tin Plate Co. v. Amalgamated Ass'n of Iron, Steel \& Tin Workers, 208 Fed. 335 (D.C. Ohio, I9I3).

${ }^{36}$ Farmers \& Mechanics National Bank v. Wilkinson, 266 U.S. 503 (I925); Union Tool Co. v. Wilson, 259 U.S. 107 (1922); In re Merchants' Stock and Grain Co., 223 U.S. 639 (I9r2).

37 In re Merchants' Stock and Grain Co., 223 U.S. 639 (IgI2). The rule was first adopted in Matter of Christensen Engineering Co., I94 U.S. 458 (1904). 
rule that would seem to imply approval of the procedure which necessitated its creation.

Mr. Justice Rutledge, in denouncing the mixed criminal and civil contempt proceeding, speaks of the procedures used in the two kinds of contempt cases as if they were alternative and conflicting. ${ }^{38}$ But the contemnor's safeguards are not alternative according to whether the charge is civil or criminal-he merely has more of them if the contempt is criminal. A contemnor can hardly complain if the charges of civil contempt against him are tried in a proceeding in which he is afforded all the protections given a criminal defendant. It is difficult to deny the government's contention in the Mine Workers case that the mixed proceeding was justified so long as the maximum criminal protections were afforded the defendants. ${ }^{39}$ The vital protective principle is still that embodied in the notice requirements of the Gompers rule; so long as that rule is complied with there would seem to be no particular danger involved in a single proceeding to try both a civil and a criminal contempt.

The District Court in the Mine Workers case imposed a single fine of $\$ 3,500,000$, which included in unspecified proportions both a criminal penalty for the contempt and civil compensation to the government for losses caused by the violation of the injunction. The Supreme Court reduced the fine to $\$ 700,000$ and made it wholly punitive, $4^{\circ}$ but it is unfortunate that in so doing the Court did not specifically condemn the form of the fine imposed by the District Court. The federal courts have accepted the levying of fines for civil contempt payable as compensation to the complaining party ${ }_{2}^{4}$ and the procedure has been adopted in a federal statute..$^{42}$ But the courts have always followed the accompanying principle that the amount of such a compensatory fine must be based on clear evidence of the complainant's losses, particularly of profits lost and the expenses of litigation. ${ }^{43}$ Since the civil contemnor is given no special procedural protections, it is essential that a fine levied against him not exceed the opposing

${ }^{38}$ United States v. United Mine Workers, 67 S. Ct. 677, 734-35 (1947).

39 United States v. United Mine Workers, Transcript of Record, pp. 197-201.

$4^{\circ}$ United States v. United Mine Workers, 67 S. Ct. 677, 701-2 (r947). An equally important problem raised in the Mine Workers case concerns the propriety of a fine of $\$ 700,000$ in punishment for an act which, if prosecuted as a violation of the War Labor Disputes Act, 57 Stat. 165 (1943), 50 U.S.C.A. Appendix § I506(b) (I944), would have drawn a maximum statutory fine of $\$ 5,000$. See the dissent of Mrr. Justice Rutledge, United States v. United Mine Workers, 67 S. Ct. 677,740 (r947); Watt, op. cit. supra note 4 , at 45 I.

${ }_{4}$ Leman v. Krentler-Arnold Hinge Last Co., 284 U.S. 448 (1932); Raymor Ballroom Co. v. Buck, 110 F. 2 d 207 (C.C.A. Ist, I940); Feldman v. American Palestine Line, I8 F. $2 d 749$ (C.C.A. 2d, I927); Morehouse v. Giant Powder Co., 206 Fed. 24 (C.C.A. gth, I913); Macauley v. White Sewing Machine Co., 9 Fed. 698 (C.C.N.Y., I88I). See Civil Contempt and Indemnity to the Plaintiff, 26 Geo. L. J. 7 I9 (I938).

${ }^{42} 38$ Stat. 738 (rgr4), 28 U.S.C.A. $\$ 387$ (r928).

43 Parker v. United States, I26 F. 2d 370 (C.C.A. Ist, I942); Norstrom v. Wahl, 4I F. 2d 910 (C.C.A. 7th, 1930); Freeman v. Premier Mach. Co., 25 F. Supp.'927 (Mass., I938); CocaCola Co. v. Feulner, 7 F. Supp. 364 (Tex., I934); Ready Roofing Co. v. Taylor, 15 Blatchf. 94 (D.C. N.Y., I878). 
party's proven pecuniary losses, lest the fine become punitive. 44 If in a mixed criminal and civil proceeding a single fine combining both elements is imposed the contemnor has no assurance that the compensatory part is not excessive. In the usual case it would be a simple matter to split the fine into its component parts; 45 and there would seem to be no reason to fear that the single mixed fine will become habitual with courts which allow a mixed criminal and civil proceeding.

It is not meant to suggest in this note either a general approval or disapproval of the Mine Workers decision or a minimizing of the need for a constant alertness against abuses of the judicial contempt power. Attacks on the contempt power which are based upon charges that the procedure employed is dangerous and unconstitutional will succeed only where the procedure criticized is shown to jeopardize specific rights and protections. It is arguable that the Supreme Court in the Mine Workers case did not apply the Gompers notice requirements with sufficient strictness; even with the Mine Workers decision on the books, however, the Gompers precedent still stands, ${ }^{46}$ and it remains as the essential protection which must be afforded parties charged with contempt of court.

${ }^{41}$ McKee Glass Co. v. H. C. Fry Glass Co., 248 Fed. I25 (C.C.A. 3d, 1918); Christensen Engineering Co. v. Westinghouse Air Brake Co., I35 Fed. 774 (C.C.A. 2d, I905).

${ }^{2}$ Cases cited notes 34 and 35 supra.

${ }^{6}$ In Penfield Co. v. Securities \& Exchange Commission, 67 S. Ct. gr8 (1947), the defendant was cited for contempt for failure to comply with a subpoena duces tecum requiring him to produce certain corporate books. The S.E.C. asked only for coercive relief but the District Court refused to grant it, and instead imposed a small punitive fine and dismissed the defendant. The Circuit Court of Appeals reversed the fine and ordered the lower court to grant the remedial relief requested by the Commission. The Supreme Court agreed, on the basis of the Gompers rule, that a punitive fine should not have been imposed. Mr. Justice Rutledge concurred, but he added that if the majority of the Court were to be consistent with the Mine Workers decision it would have to let the fine stand. If the interpretation outlined in this note is correct, the Mine Workers decision had no such effect on the Gompers precedent as Mr. Justice Rutledge asserts. 